\title{
Penggerombolan Data Panel Perusahaan Sektor Barang Konsumsi
}

\author{
Radinda Putri Maha Dewi*, Pika Silvianti, $\mathrm{MSi}^{*}$, Septian Rahardiantoro, $\mathrm{MSi}^{*}$ \\ *Departemen Statistika Institut Pertanian Bogor
}

\begin{abstract}
Abstrak-The identification of the cluster of consumer goods sector companies is enough important study to examine the characteristics of the company based on its marketing management factors. This study seeks to cluster 23 consumer goods sector companies based on 4 marketing management factors, which are production costs, promotion costs, distribution costs, and sales value in 2012-2016. There are two parts of clustering that are carried out, the clustering of consumer goods sector companies based on the time series pattern for each marketing management factor with the ward method, and clustering of consumer goods sector companies using multivariate panel data using the k-means method. The results of the clustering for each marketing management factor using the ward method produced 2 groups in each factor, with cluster 2 having an average of each factor greater than group 1 . The companies found in cluster 2 were PT Indofood CBP Sukses Makmur, PT Indofood Sukses Makmur, PT Mayora Indah, PT Unilever Indonesia Tbk, PT Handjaya Mandala Sampoerna Tbk, International Investama Tbk, PT Kalbe Farma Tbk, and PT Tempo Scan Pacific Tbk. On the other hand, clustering of multivariate panel data produced 6 groups where group 5 is the cluster with the highest average on each factor. Group 5 consists of PT Indofood Sukses Makmur and PT Handjaya Mandala Sampoerna Tbk. The company with the highest value in multivariate panel data is also found in the results of the cluster with the highest value for each marketing management factor.

Kata kunci-penggerombolan data panel multivariat; faktor manajemen pemasaran; penggerombolan deret waktu
\end{abstract}

\section{PENDAHULUAN}

\section{A. Latar Belakang}

Saat ini, banyak perusahaan sektor barang konsumsi yang bersaing di Indonesia. Sektor barang konsumsi yang dimaksud adalah sektor makanan dan minuman, sektor barang kosmetik dan barang keperluan rumah tangga, sektor peralatan rumah tangga serta sektor rokok. Praktiknya, setiap perusahaan pasti memperhatikan kriteria marketing atau manajemen pemasaran untuk menarik pelanggan sehingga memperoleh keuntungan yang maksimum. Beberapa faktor penting dalam manajemen pemasaran perusahaan sektor barang konsumsi yaitu biaya produksi, biaya promosi, biaya distribusi, dan nilai penjualan. Biaya produksi merupakan besarnya biaya yang dikeluarkan oleh perusahaan selama proses pembuatan produk (Riwayadi (2006)). Biaya promosi merupakan biaya yang dikeluarkan untuk memasarkan atau memperkenalkan suatu produk (William et al. (2004)). Biaya distribusi merupakan biaya yang dikeluarkan untuk menyalurkan produk (Ardiyoso (2007)). Nilai penjualan menjadi salah satu kriteria pemasukan dari perusahaan untuk melihat seberapa besar minat masyarakat terhadap produk yang dijual (?). Pola nilai faktor-faktor manajemen pemasaran pada perusahaan sektor barang konsumsi tentunya berbeda dari satu perusahaan dengan yang lainnya. Kondisi yang serupa juga akan diperoleh apabila dilihat dari pola waktu ke waktu.Penelitian ini, berupaya untuk mengidentifikasi perusahaan sektor barang konsumsi yang memiliki pola nilai faktor-faktor manajemen pemasaran yang sama dari waktu ke waktu untuk setiap faktor manajemen pemasarannya maupun secara keseluruhan. Oleh karena itu, metode yang digunakan adalah metode penggerombolan (cluster analysis). Data yang digunakan merupakan nilai biaya produksi, biaya distribusi, biaya promosi, dan nilai penjualan dari 23 perusahaan sektor barang konsumsi pada tahun 20122016. Metode penggerombolan yang digunakan untuk mengidentifikasi perusahaan dengan pola yang sama setiap tahun pada masing-masing faktor manjemen pemasaran adalah metode ward. Metode tersebut dipilih karena meminimumkan Error Of Sum Square yang merupakan ukuran kedekatan amatan yang akan tergabung dalam satu gerombol 
(Johnson and Wichern (2007)). Selain itu, penggunaan metode penggerombolan data panel (clustering panel data) dipilih karena untuk mengidentifikasi perusahaan dengan pola yang sama pada setiap tahun untuk semua faktor manajemen pemasaran (Genolini et al. (2015)). Penerapannya, metode penggerombolan data panel yang digunakan adalah metode k-means. Hal ini didukung oleh penelitian yang dilakukan oleh Ilmarinen et al. (2007) mengenai penggerombolan pasien penderita asma ketika sudah dalam usia dewasa. Hasilnya, metode k-means mampu menggerombolkan dengan baik meskipun data yang digunakan tersebut merupakan data panel. Secara singkat, penelitian ini berupaya untuk menelaah gerombol perusahaan sektor barang konsumsi berdasarkan pola tahunannya pada masing-masing faktor manajemen pemasarannya dengan metode ward. Selanjutnya, penggerombolan perusahaan sektor barang konsumsi tersebut juga dilakukan dengan dipandang sebagai data panel dengan menggunakan penggerombolan data panel k-means. Semua analisis data dilakukan dengan menggunakan software $\mathrm{R}$.

\section{B. Tujuan}

1) Identifikasi gerombol perusahaan sektor barang konsumsi berdasarkan masingmasing pola tahunan faktor manajemen pemasarannya, dalam hal ini peubah biaya produksi, peubah biaya promosi, peubah biaya distribusi, dan peubah nilai penjualan.

2) Identifikasi gerombol perusahaan sektor barang konsumsi berdasarkan pola tahunan untuk seluruh peubah (peubah biaya produksi, peubah biaya promosi, peubah biaya distribusi, dan peubah nilai penjualan) secara multivariat.

\section{TINJAUAN PUSTAKA}

\section{A. Perusahaan Sektor Barang Konsumsi}

Perusahaan sektor barang konsumsi merupakan perusahaan yang bergerak pada bidang konsumsi. Barang konsumsi menjadi salah satu industri utama berkembang yang berhasil di Indonesia. Hal ini dapat disebabkan dengan jumlah penduduk lebih dari 240 juta penduduk yang tak terlepas dari kegiatan konsumsi. Berdasarkan IDX Fact Book 2016, terdapat 9 sektor perusahaan yang ada di Indonesia yaitu 1) sektor pertanian, 2) sektor pertambangan, 3) sektor industri dasar dan bahan kimia, 4) sektor aneka industri, 5) sektor perusahaan barang konsumsi, 6) sektor properti, perumahan, dan kontruksi pembangunan, 7) sektor infrastruktur, utilitas, dan transportasi, 8) sektor keuangan, 9) perdagangan, servis, dan investasi. Penelitian ini hanya menggunakan satu sektor yaitu sektor perusahaan barang konsumsi yang terdiri dari 5 sektor perusahaan barang konsumsi. Sektor perusahaan barang konsumsi yang digunakan dalam penelitian ini yaitu sektor makanan dan minuman, sektor kosmetik dan barang keperluan rumah tangga, sektor peralatan rumah tangga, dan sektor rokok. Perusahaan sektor barang konsumsi pasti ingin mencapai keuntungan maksimum. Oleh karena itu, perusahaan sektor barang konsumsi memperhatikan manajemen pemasaran untuk mengelola perusahaan guna tercapai tujuan tersebut. Beberapa faktor penting pada penelitian ini dalam hal manajemen pemasaran perusahaan sektor barang konsumsi yaitu biaya produksi, biaya promosi, biaya distribusi, dan nilai penjualan.

\section{B. Data Panel}

Data panel merupakan bentuk data gabungan antara bentuk time series data dan bentuk cross section data. Cross section data merupakan data yang terdiri atas beberapa amatan dalam satu waktu pengamatan sedangkan time series data merupakan data yang terdiri atas satu objek yang diamati pada beberapa waktu yang berbeda (Winarno (2007)). Sehingga, data panel merupakan data yang terdiri dari beberapa amatan yang masing-masing amatan diamati beberapa waktu berdasarkan suatu peubah tertentu. Sebagai ilustrasi, data panel merupakan bentuk pada kasus data yang berkaitan dengan orang, perusahaan, negara, dan lain-lain seperti nilai PDRB dan nilai PDB dari masing-masing provinsi dari waktu ke waktu. Lebih lanjut, pengamatan pada data panel dapat bersifat pengamatan univariat maupun multivariat. Data panel univariat berarti terdapat beberapa amatan yang diamati pada beberapa waktu berdasarkan satu peubah, sedangkan data panel multivariat merupakan beberapa amatan yang diamati beberapa waktu untuk lebih dari satu peubah. Penelitian ini, menggunakan sajian 
kasus data panel yang bersifat multivariat karena melibatkan 23 perusahaan sektor barang konsumsi yang diamati selama 5 tahun untuk peubah biaya produksi, biaya promosi, biaya distribusi, dan nilai penjualan.

\section{Analisis Gerombol}

Analisis gerombol adalah analisis yang berupaya untuk menelaah gerombol amatan berdasarkan kesamaan karakteristik peubah-peubahnya. Suatu amatan dikatakan memiliki karakteristik yang sama jika memiliki jarak yang berdekatan. Jarak yang sering digunakan yaitu jarak euclid.

Analisis gerombol yang umum digunakan dibedakan menjadi dua metode yaitu metode berhirarki dan metode non-hirarki. Penentuan banyaknya gerombol pada metode berhirarki didasarkan pada pola dendogram dari proses penggerombolannya, sehingga banyak gerombol belum diketahui pada awal analisis. Analisis gerombol berhirarki pada penelitian ini, digunakan untuk menggerombolkan perusahaan sektor barang konsumsi berdasarkan pola waktu untuk masing-masing faktor manajemen pemasaran. Metode analisis gerombol berhirarki yang digunakan pada penelitian ini yaitu metode ward. Metode ward bertujuan menggerombolkan amatan dengan meminimumkan Error of Sum Squares (ESS).Berikut ini adalah tahapan proses penggerombolan metode ward.

1) Asumsikan setiap data dianggap sebagai gerombol.

2) Bentuk gerombol dimana sebuah gerombol terdiri dari pasangan dua objek sehingga kemungkinan jumlah gerombol $C_{2}^{n}$, kemudian hitung ESS dari semua pasangan gerombol.

3) Hitung nilai ESS dan pilih ESS terkecil kemudian pasangan dari gerombol tersebut digabungkan.

4) Ulangi langkah 2 dan 3 sampai membentuk satu gerombol. (Johnson and Wichern (2007)).

Pada lain sisi, penentuan banyak gerombol pada metode non-hirarki ditentukan pada awal analisis. Hal ini tentunya berkebalikan dengan prinsip penggerombolan dengan metode hirarki. Salah satu dari metode non-hirarki yaitu metode k-means. Metode k-means merupakan metode penggerombolan yang menggerombolkan objek berdasarkan titik pusat gerombol (centroid) terdekat dengan objek. Tujuan dari k-means yaitu memaksimalkan objek dengan karakteristik yang sama dalam satu gerombol dan meminimalkan kemiripan objek antar gerombol yang lain. Kemiripan objek dapat dimaksimalkan berdasarkan jarak terpendek antara objek terhadap titik centroid. Penelitian ini menggunakan metode k-means dalam penggerombolan perusahaan sektor barang konsumsi berdasarkan pola seluruh waktu dan seluruh peubah dalam bentuk data panel multivariat. Berikut ini merupakan algoritma k-means secara umum, sedangkan metode k-means pada data panel multivariat akan dijelaskan pada bagian selanjutnya. Algoritma k-means diuraikan sebagai berikut (Prasetyo (2012)) :

1) Menentukan k sebagai jumlah gerombol yang ingin dibentuk

2) Mengalokasikan data ke dalam gerombol secara acak

3) Menentukan pusat gerombol (centroid) dari data yang ada pada masing-masing gerombol dengan persamaan :

$$
C_{g j}=\frac{\sum_{i \epsilon G_{g}} x_{i j}}{n_{b}}
$$

dimana

$C_{g j}=$ pusat gerombol ke-g $(\mathrm{g}=1,2, \mathrm{k})$ pada variabel ke-j $(\mathrm{j}=1,2, \ldots, \mathrm{p})$

$G_{g}=$ himpunan indeks anggota gerombol ke-g

$n_{g}=$ banyak observasi pada gerombol ke-g

4) Menentukan jarak setiap objek dengan setiap centroid dengan perhitungan jarak setiap objek dengan setiap centroid menggunakan jarak euclid.

5) Mengalokasikan masing-masing data ke centroid.

6) Mengulangi kembali langkah 3-5 sampai tidak ada lagi perpindahan objek atau tidak ada perubahan pada fungsi objektifnya.

\section{Analisis Gerombol Data Panel}

Salah satu alternatif metode atau algoritma analisis gerombol yang digunakan pada data panel dapat menyerupai analisis gerombol yang digunakan pada umumnya yaitu menggunakan analisis 
gerombol berhirarki dan analisis gerombol nonhirarki. Namun, pada metode ini memiliki prosedur yang berbeda pada tahap pre-processing. Tahap pre-processing yaitu mempersiapkan data agar data dapat dilakukan analisis gerombol data panel (clustering panel data).

Pada praktiknya, metode analisis gerombol data panel multivariat pada penelitian ini meliputi tiga tahapan utama, yaitu tahapan pre-processing data, tahapan penggerombolan dengan metode k-means, dan tahapan evaluasi banyak gerombol terbentuk. Pada penelitian ini, tahapan analisis gerombol data panel (clustering panel data) terdiri dari beberapa tahap. Tahap pertama yang dilakukan yaitu membentuk data agar dapat dilakukan analisis gerombol data panel (pre-processing).

Tahap kedua membentuk matriks jointtrajectories yang merupakan kumpulan dari beberapa variable-trajectory. Variable-trajectory adalah variabel atau peubah yang sama diukur berulang kali dari waktu ke waktu. Tahap ketiga melakukan analisis gerombol k-means. Penentuan banyak gerombol optimum yang terbentuk dilakukan dengan perhitungan Calinski Harabaz Criterion. Selanjutnya, pada tahap keempat mengalokasikan data ke dalam gerombol secara acak. Tahap kelima, menentukan pusat gerombol (centroid) dari data yang ada pada masing-masing gerombol. Setelah pusat gerombol (centroid) terbentuk, menentukan jarak setiap objek dengan setiap centroid dengan perhitungan jarak setiap objek dengan setiap centroid menggunakan jarak euclid. Kemudian, Mengalokasikan masing-masing data ke centroid/rata-rata terdekat. Lakukan kembali dari tahap kedua hingga tidak ada lagi perpindahan objek (Genolini et al. (2015)). Kebaikan gerombol yang dibentuk untuk analisis k-means menggunakan Calinski Harabaz Criterion dengan rumus sebagai berikut.

$$
C_{k}=\frac{\operatorname{Trace}(\beta)}{\operatorname{Trace}(W)} \cdot \frac{n-k}{k-1}
$$

Keterangan :

Trace $(B)=$ Nilai trace dari matrix covariance antar gerombol

Trace $(\mathrm{W})=$ Nilai trace dari matrix covariance dalam gerombol

$\mathrm{n}=$ Jumlah objek

$\mathrm{k}=$ Jumlah k-gerombol
Berdasarkan perhitungan Calinski Harabaz Criterion, semakin besar nilai Calinski Harabaz Criterion maka semakin baik. Hal itu disebabkan semakin besar nilai Calinski Harabaz Criterion maka nilai trace dari matrix covariance antar gerombol semakin besar atau perbedaan antar gerombolnya semakin besar sedangkan kemiripan dalam gerombolnya semakin besar juga. (Calinski and Harazbasz (1974))

\section{METODOLOGI}

\section{A. Data}

Data yang digunakan dalam penelitian ini adalah data sekunder mengenai perusahaan sektor barang konsumsi yang diperoleh dari laporan keuangan Bursa Efek Indonesia (IDX). Data tersebut terdiri atas 23 perusahaan sektor barang konsumsi dengan peubah yang digunakan yaitu biaya produksi, biaya promosi, biaya distribusi, dan nilai penjualan dengan rentang waktu 5 tahun (20122016). Berikut penjelasan lebih rinci peubah yang digunakan seperti yang terdapat pada Tabel 1 .

Tabel I

DAFTAR PEUBAH YANG DIGUNAKAN BESERTA KETERANGANNYA

\begin{tabular}{lclll}
\hline Kode Peubah & nama peubah & \multicolumn{1}{c}{ penjelasan } & satuan \\
\hline X1 & $\begin{array}{c}\text { Biaya } \\
\text { produksi }\end{array}$ & $\begin{array}{l}\text { Total biaya produksi yang } \\
\text { digunakan selama 12 bulan } \\
\text { pada tahun 2012- 2016. }\end{array}$ & rupiah \\
& Biaya & $\begin{array}{l}\text { Total biaya promosi yang } \\
\text { digunakan selama 12 bulan } \\
\text { pada tahun 2012-2016. }\end{array}$ & \\
& promosi & Total biaya distribusi yang & rupiah \\
digunakan selama 12 bulan & \\
p3 & Biaya & distribusi & Total nilai penjualan yang & rupiah \\
& Nilai & $\begin{array}{l}\text { diperoleh selama 12 bulan } \\
\text { pada tahun 2012-2016. }\end{array}$ & \\
\hline X4 & & &
\end{tabular}

\section{B. Metode}

Tahapan analisis gerombol data data terhadap data perusahaan sektor barang konsumsi sebagai berikut:

1) Melakukan eksplorasi data secara deskriptif. Eksplorasi data ini dilakukan untuk melihat karakteristik seperti : a. Pola tahunan nilai peubah biaya produksi, biaya promosi, biaya 
distribusi, dan nilai penjualan untuk setiap perusahaan berdasarkan sektor barang konsumsi. b. Pola rata-rata nilai peubah masing-masing sektor.

2) Melakukan analisis gerombol pada setiap peubah berdasarkan pola waktunya dengan metode ward.

3) Melakukan analisis gerombol data panel secara multivariat dengan metode k-means, dengan nilai $\mathrm{k}=2,3,4,5,6$.

4) Menginterprestasikan hasil yang diperoleh. Hasil yang diperoleh berupa jumlah gerombol dari masing-masing analisis yang digunakan yaitu hasil dari analisis gerombol berhirarki dan non-hirarki.

\section{HASIL DAN PEMBAHASAN}

A. Penggerombolan Berdasarkan Pola Tahunan Setiap Peubah

\section{Penggerombolan Biaya Produksi}

Penelitian penggerombolan dengan analisis gerombol berhirarki menggunakan metode ward terhadap masing-masing peubah. Hasil penggerombolan diperoleh berdasarkan hasil eksplorasi dari grafik dendogram dan plot deret waktu yang dilakukan dengan menggunakan jarak euclid.

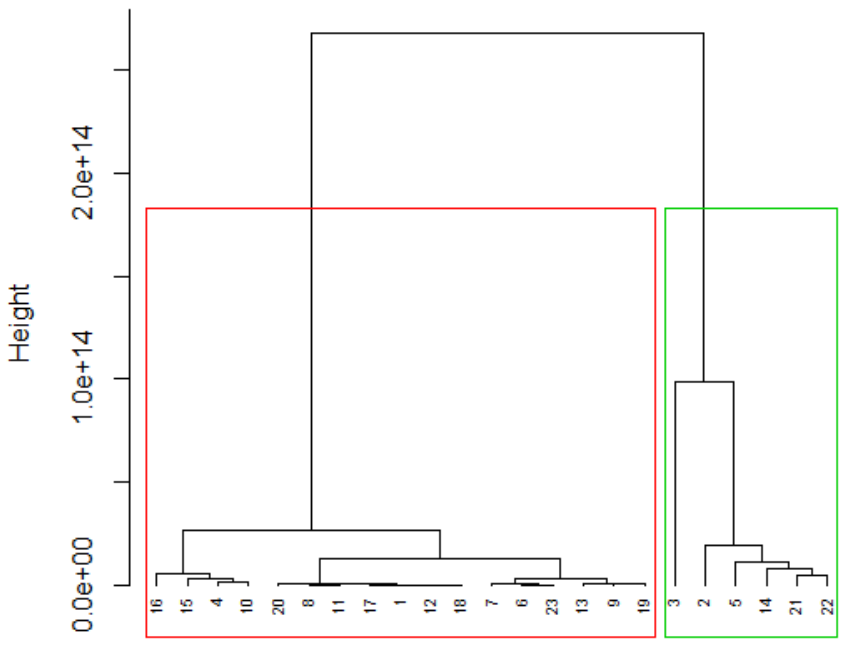

Gambar 1. Hasil dendogram penggerombolan perusahaan berdasarkan peubah biaya produksi

Berdasarkan Gambar 1 diperoleh dua gerombol berdasarkan waktu yang digunakan. Gerombol per- tama terdiri dari 1 perusahaan dan gerombol kedua yang terbentuk terdiri dari 6 perusahaan.

Tabel II

DAFTAR PERUSAHAAN UNTUK PENGGEROMBOLAN BERDASARKAN PEUBAH BIAYA PRODUKSI

\begin{tabular}{ll}
\hline \multicolumn{1}{c}{ Gerombol 1 } & \multicolumn{1}{c}{ Gerombol 2} \\
\hline PT Delta Djakarta, Tbk & $\begin{array}{l}\text { PT Indofood CBP Sukses } \\
\text { Makmur }\end{array}$ \\
PT Ultra jaya & PT Indofood Sukses Makmur \\
PT Multi Bintang Indonesia & PT Mayora Indah, Tbk \\
PT Nippon Indosari Corpindo & PT Unilever Indonesia Tbk \\
PT Sekar Laut & PT Handjaya Mandala Sam- \\
& poerna Tbk \\
PT Siantar Top & PT Bentoel International In- \\
& vestama Tbk \\
PT Tiga Pilar Sejahtera, Tbk & \\
PT Akasha Wira International & \\
Tbk & \\
PT Mustika Ratu Tbk & \\
PT Mandom Indonesia Tbk & \\
PT Kimia Farma Tbk & \\
PT Kalbe Farma Tbk & \\
PT Pyridam Farma Tbk & \\
PT Taisho Pharmaceutical In- & \\
donesia Tbk & \\
PT Tempo Scan Pasific Tbk & \\
PT Langgeng Makmur Indus- & \\
tri Tbk & \\
PT Wismilak Inti Makmur & \\
Tbk & \\
\hline
\end{tabular}

Perusahaan-perusahaan yang terdapat pada gerombol pertama menunjukkan bahwa perusahaan tersebut memiliki karakteristik yang sama dalam hal biaya produksi (Tabel 2). Begitu pun, perusahaan yang terdapat pada gerombol kedua. Perusahaan pada gerombol pertama didominasi oleh perusahaan kosmetik dan keperluan rumah tangga. Sedangkan, pada perusahaan gerombol kedua merupakan perusahaan yang bergerak di sektor makanan dan minuman, kosmetik dan barang keperluan rumah tangga, dan rokok.

Jika dilihat dari rata-rata biaya produksi 20122016 pada Tabel 3, gerombol kedua lebih besar dibandingkan dengan biaya produksi pada gerombol pertama. Perusahaan-perusahaan yang terdapat pada gerombol kedua seperti yang terdapat pada gambar 6 merupakan perusahaan yang bergerak pada sektor makanan dan minuman, rokok, kosmetik dan peralatan rumah tangga yang produknya cukup dikenal di kalangan masyarakat. 
Tabel III

NILAI RATA-RATA DAN SIMPANGAN BAKU SETIAP GEROMBOL TERBENTUK BERDASARKAN BIAYA PRODUKSI PADA TAHUN 2012-2016

\begin{tabular}{lllll}
\hline tahun & rata-rata G1 & rata-rata G2 & Stdev G1 & Stdev G2 \\
\hline 2012 & 0.880 & 15.604 & 0.863 & 10.156 \\
2013 & 1.091 & 17.743 & 1.097 & 11.434 \\
2014 & 1.410 & 19.673 & 1.391 & 11.351 \\
2015 & 1.515 & 20.277 & 1.520 & 11.156 \\
2016 & 1.637 & 21.834 & 1.659 & 10.923 \\
\hline
\end{tabular}

Jika dibandingkan hasil simpangan baku dari masing-masing tahun tersebut, nilai simpangan baku biaya produksi 2012-2016 pada gerombol 2 lebih besar dibandingkan dengan gerombol 1. Hal ini menunjukkan gerombol 2 memiliki keragaman data yang lebih besar dibandingkan gerombol 1. Hal ini disebabkan adanya perbedaan biaya produksi yang cukup tinggi antara perusahaan sektor makanan dan minuman yang memiliki biaya produksi lebih tinggi dibandingkan perusahaan sektor rokok.

\section{Penggerombolan Biaya Promosi}

Biaya promosi dikeluarkan oleh perusahaan sebagai biaya untuk memperkenalkan produk yang akan di pasarkan kepada masyarakat.

Hasil penggerombolan berhirarki dengan menggunakan metode ward dapat dilihat pada Gambar 2. Penggerombolan berdasarkan pada jarak euclid sehingga diperoleh dua gerombol. Pada gerombol 1 terdapat 15 perusahaan sedangkan gerombol 2 terdapat 8 perusahaan.

Pada Tabel 4 menunjukkan perusahaanperusahaan yang termasuk pada gerombol 1 dan gerombol 2. Gerombol 2 berisi perusahaan dari sektor rokok, sektor makanan dan minuman, sektor kosmetik dan barang keperluan rumah tangga sedangkan gerombol 1 berisi perusahaan dengan biaya promosi.

Berdasarkan Tabel 5, rata-rata biaya promosi dari tahun ke tahun cenderung meningkat. Gerombol 2 memiliki rata-rata biaya promosi dari tahun ke tahun lebih besar dibandingkan dengan gerombol 1 .

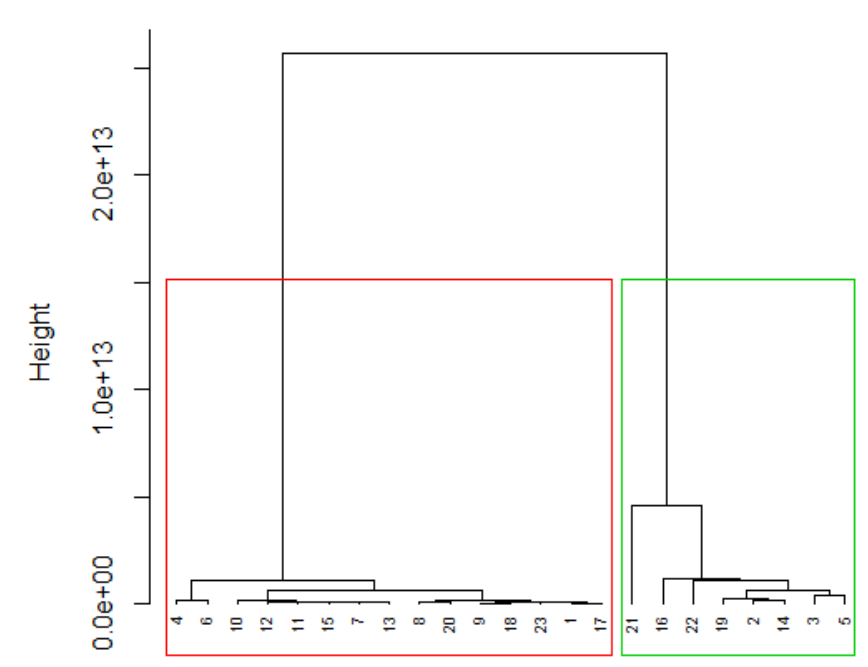

Gambar 2. Hasil dendogram penggerombolan perusahaan berdasarkan peubah biaya promosi

Perusahaan-perusahaan yang terdapat pada gerombol 2 merupakan perusahaan yang jenis produknya cukup dikenal dikalangan masyarakat yang bergerak pada sektor makanan dan minuman, rokok, kosmetik dan peralatan rumah tangga.

Pada Tabel 5 juga menunjukkan nilai simpangan baku tahun 2012-2016 dari masing-masing gerombol. Dari hasil standar deviasi tersebut, terlihat simpangan baku biaya promosi tahun 2012-2016 pada gerombol 2 lebih besar dibandingkan dengan gerombol 1. Hal ini menunjukkan bahwa gerombol 2 memiliki keragaman data lebih besar dibandingkan gerombol 1 yang disebabkan perusahaan pada gerombol 2 memiliki perbedaan biaya promosi yang cenderung tinggi.

\section{Penggerombolan Biaya Distribusi}

Penelitian penggerombolan biaya distribusi sama dengan penggerombolan terhadap biaya produksi dan biaya promosi. Penggerombolan dilakukan dengan analisis gerombol berhirarki yaitu metode ward berdasarkan jarak euclid.

Berdasarkan Gambar 3 hasil dendogram menunjukkan hasil 2 gerombol. Gerombol 1 terdiri dari 20 perusahaan dan gerombol 2 terdiri dari 3 perusahaan. Pada masing-masing gerombol menunjukkan bahwa perusahaan tersebut memiliki karakteristik yang sama. 
Tabel IV

DAFTAR PERUSAHAAN UNTUK PENGGEROMBOLAN BERDASARKAN PEUBAH BIAYA PROMOSI

\begin{tabular}{|c|c|c|c|}
\hline No & Gerombol 1 & No & Gerombol 2 \\
\hline 1 & PT Delta Djakarta, Tbk & 1 & $\begin{array}{l}\text { PT Indofood CBP Suk- } \\
\text { ses Makmur }\end{array}$ \\
\hline 2 & PT Ultra jaya & 2 & $\begin{array}{l}\text { PT Indofood Sukses } \\
\text { Makmur }\end{array}$ \\
\hline 3 & $\begin{array}{l}\text { PT Multi Bintang In- } \\
\text { donesia }\end{array}$ & 3 & PT Mayora Indah, Tbk \\
\hline 4 & $\begin{array}{l}\text { PT Nippon Indosari } \\
\text { Corpindo }\end{array}$ & 4 & $\begin{array}{l}\text { PT Unilever Indonesia } \\
\text { Tbk }\end{array}$ \\
\hline 5 & PT Sekar Laut & 5 & PT Kalbe Farma Tbk \\
\hline 6 & PT Siantar Top & 6 & $\begin{array}{l}\text { PT Tempo Scan Pasific } \\
\text { Tbk }\end{array}$ \\
\hline 7 & $\begin{array}{l}\text { PT Tiga Pilar Sejahtera, } \\
\text { Tbk }\end{array}$ & 7 & $\begin{array}{l}\text { PT Handjaya Mandala } \\
\text { Sampoerna Tbk }\end{array}$ \\
\hline 8 & $\begin{array}{l}\text { PT Akasha Wira Inter- } \\
\text { national Tbk }\end{array}$ & 8 & $\begin{array}{lr}\text { PT } & \text { Bentoel } \\
\text { International } & \text { Investama } \\
\text { Tbk }\end{array}$ \\
\hline 9 & PT Mustika Ratu Tbk & & \\
\hline 10 & $\begin{array}{l}\text { PT Mandom Indonesia } \\
\text { Tbk }\end{array}$ & & \\
\hline 11 & PT Kimia Farma Tbk & & \\
\hline 12 & PT Pyridam Farma Tbk & & \\
\hline 13 & $\begin{array}{l}\text { PT Taisho Pharmaceuti- } \\
\text { cal Indonesia Tbk }\end{array}$ & & \\
\hline 14 & $\begin{array}{l}\text { PT Langgeng Makmur } \\
\text { Industri Tbk }\end{array}$ & & \\
\hline 15 & $\begin{array}{l}\text { PT Wismilak Inti Mak- } \\
\text { mur Tbk }\end{array}$ & & \\
\hline
\end{tabular}

Tabel V

NILAI RATA-RATA DAN SIMPANGAN BAKU SETIAP GEROMBOL TERBENTUK BERDASARKAN BIAYA PROMOSI PADA TAHUN 2012-2016

\begin{tabular}{lllll}
\hline tahun & rata-rata G1 & rata-rata G2 & Stdev G1 & Stdev G2 \\
\hline 2012 & 0.066 & 0.927 & 0.049 & 0.322 \\
2013 & 0.088 & 1.150 & 0.073 & 0.277 \\
2014 & 0.084 & 1.316 & 0.063 & 0.521 \\
2015 & 0.095 & 1.479 & 0.067 & 0.607 \\
2016 & 0.117 & 1.682 & 0.087 & 0.457 \\
\hline
\end{tabular}

Pada Tabel 6 terlihat perusahaan yang terdapat pada gerombol 2 merupakan perusahaan yang bergerak di sektor makanan dan minuman, kosmetik dan barang keperluan rumah tangga. Pada gerombol 1 terdiri dari perusahaan di sektor makanan dan

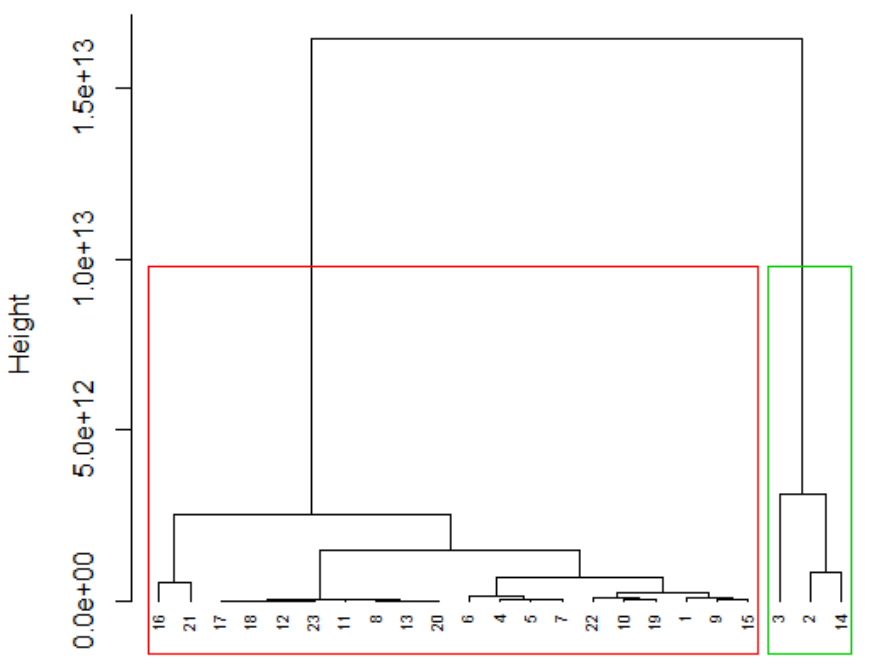

Gambar 3. Hasil dendogram penggerombolan perusahaan berdasarkan peubah biaya distribusi

Tabel VI

DAFTAR PERUSAHAAN UNTUK PENGGEROMBOLAN BERDASARKAN PEUBAH BIAYA DISTRIBUSI

\begin{tabular}{lrllr}
\hline & \multicolumn{3}{c}{ Gerombol 1 } & \\
\hline PT Delta & Djakarta, Tbk,PT Ultra & PT & Indofood & CBP \\
jaya,PT & Mayora Indah, Tbk,PT & Sukses & Makmur,PT \\
Multi & Bintang & Indonesia,PT & Indofood & Sukses \\
Nippon & Indosari & Corpindo,PT & Makmur,PT & Unilever \\
Sekar Laut,PT Tiga Pilar Sejahtera, & Tbk & \\
Tbk,PT Akasha Wira International & & \\
Tbk,PT Mustika Ratu Tbk, PT & \\
Mandom Indonesia Tbk,PT Kimia & \\
Farma Tbk,PT Kalbe Farma & \\
Tbk,PT Pyridam Farma Tbk,PT & \\
Taisho Pharmaceutical Indonesia & \\
Tbk,PT Tempo Scan Pasific Tbk,PT & \\
Langgeng Makmur Industri Tbk,PT & \\
Handjaya Mandala Sampoerna & \\
Tbk,PT Bentoel International & \\
Investama Tbk, PT Wismilak Inti & \\
Makmur Tbk & \\
\hline
\end{tabular}

minuman, kosmetik dan barang keperluan rumah tangga, peralatan rumah tangga dan rokok.

Berdasarkan Tabel 7 keseluruhan gerombol mengalami peningkatan rata-rata biaya distribusi dari tahun ke tahun. Jika dibandingkan antar gerombolnya, dari tahun 2012-2016, rata-rata biaya distribusi perusahaan pada gerombol 2 lebih besar dibandingkan gerombol 1.

Keragaman data antar gerombol dapat juga diketahui dari hasil simpangan baku seperti pada Tabel 
Tabel VII

NILAI RATA-RATA DAN SIMPANGAN BAKU SETIAP GEROMBOL TERBENTUK BERDASARKAN BIAYA DISTRIBUSI PADA TAHUN 2012-2016

\begin{tabular}{lllll}
\hline tahun & rata-rata G1 & rata-rata G2 & Stdev G1 & Stdev G2 \\
\hline 2012 & 0.067 & 1.211 & 0.092 & 0.495 \\
2013 & 0.089 & 1.455 & 0.107 & 0.590 \\
2014 & 0.104 & 1.821 & 0.126 & 0.724 \\
2015 & 0.121 & 1.945 & 0.162 & 0.667 \\
2016 & 0.131 & 2.033 & 0.177 & 0.629 \\
\hline
\end{tabular}

7. Hasil simpangan baku biaya distribusi 2012 pada gerombol 2 lebih besar dibandingkan dengan gerombol 1. Begitu pun pada hasil standar deviasi biaya distribusi 2013-2016. Hal ini menunjukkan bahwa keragaman data dari tahun ke tahun pada gerombol 2 lebih besar dibandingkan dengan gerombol 1. Hal ini dapat disebabkan adanya perbedaan biaya distribusi yang cukup tinggi antar perusahaan pada gerombol 2 .

\section{Penggerombolan Nilai Penjualan}

Penggerombolan terhadap nilai penjualan dilakukan dengan metode ward berdasarkan jarak euclid.

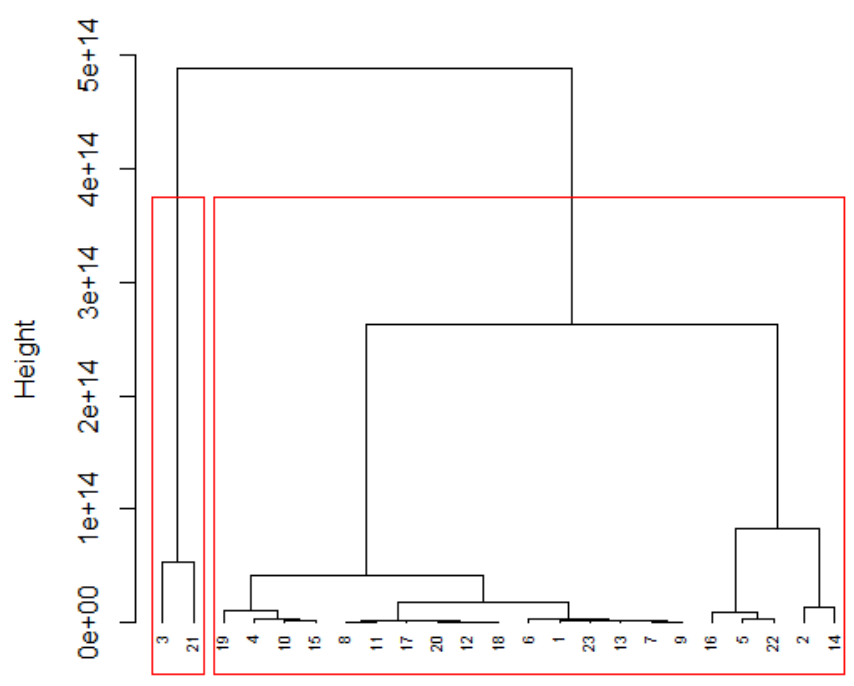

Gambar 4. Hasil dendogram penggerombolan perusahaan berdasarkan peubah nilai penjualan
Hasil dendogram pada Gambar 4 menunjukkan penggerombolan yang dilakukan menghasilkan 2 gerombol. Gerombol 1 terdiri dari 21 perusahaan dan gerombol 2 terdiri dari 2 perusahaan.

Tabel VIII

DAFTAR PERUSAHAAN UNTUK PENGGEROMBOLAN BERDASARKAN PEUBAH NILAI PENJUALAN

\begin{tabular}{ll}
\hline \multicolumn{1}{c}{ Gerombol 1 } & \multicolumn{2}{c}{ Gerombol 2} \\
\hline PT Delta Djakarta, Tbk, PT Indo- & PT Indofood Sukses \\
food CBP Sukses Makmur,PT Ul- & Makmur, PT Handjaya \\
tra jaya, PT Mayora Indah, Tbk, & Mandala Sampoerna \\
PT Multi Bintang Indonesia, PT & Tbk \\
Nippon Indosari Corpindo,PT Sekar & \\
Laut, PT Siantar Top, PT Tiga & \\
Pilar Sejahtera, Tbk, PT Akasha & \\
Wira International Tbk, PT Mustika \\
Ratu Tbk,PT Mandom Indonesia \\
Tbk, PT Unilever Indonesia Tbk, \\
PT Kimia Farma Tbk,PT Kalbe \\
Farma Tbk, PT Pyridam Farma \\
Tbk, PT Taisho Pharmaceutical \\
Indonesia Tbk, PT Tempo Scan \\
Pasific Tbk,PT Langgeng Makmur \\
Industri Tbk, PT Bentoel Interna- \\
tional Investama Tbk, PT Wismilak \\
Inti Makmur Tbk \\
\hline
\end{tabular}

Berdasarkan Tabel 8, gerombol 2 terdiri dari perusahaan di sektor rokok, makanan dan minuman sedangkan gerombol 1 terdiri dari perusahaan di sektor makanan dan minuman, kosmetik dan barang keperluan rumah tangga, keperluan rumah tangga, dan rokok. Berdasarkan hasil analisis deskriptif, gerombol 2 berisi perusahaan dengan nilai penjualan lebih dari 50 triliun rupiah sejak tahun 2012 sedangkan gerombol 1 berisi perusahaan dengan nilai penjualan kurang dari 50 triliun rupiah.

Rata-rata nilai penjualan dari tahun 2012-2016 pada Tabel 9 menunjukkan bahwa rata-rata nilai penjualan pada gerombol 2 lebih besar dibandingkan gerombol 1. Rata-rata nilai penjualan tertinggi terdapat pada gerombol 2 sebesar 81.108487 triliun rupiah.

Berdasarkan Tabel 9, hasil simpangan baku nilai penjualan menunjukkan gerombol 2 memiliki nilai simpangan baku yang lebih besar dibandingkan gerombol 1 dari tahun ke tahun. Hal ini menunjukkan gerombol 2 memiliki keragaman data yang besar dibandingkan gerombol 1. Hal ini dapat disebabkan adanya perbedaan nilai penjualan antar perusahaan yang cukup tinggi pada gerombol 2 . 
Tabel IX

NILAI RATA-RATA DAN SIMPANGAN BAKU SETIAP GEROMBOL TERBENTUK BERDASARKAN NILAI PENJUALAN PADA TAHUN 2012-2016

\begin{tabular}{lllll}
\hline tahun & rata-rata G1 & rata-rata G2 & Stdev G1 & Stdev G2 \\
\hline 2012 & 5.239 & 58.342 & 7.468 & 11.714 \\
2013 & 6.189 & 66.379 & 8.505 & 12.228 \\
2014 & 7.033 & 72.142 & 9.787 & 12.089 \\
2015 & 7.493 & 76.566 & 10.390 & 17.683 \\
2016 & 8.345 & 81.109 & 11.472 & 20.306 \\
\hline
\end{tabular}

Pada gerombol 2 perusahaan sektor rokok memiliki nilai penjualan lebih tinggi dengan nilai penjualan antara 60 sampai 100 triliun rupiah dibandingkan perusahaan sektor makanan dan minuman.

\section{Penggerombolan Data Panel Multivariat}

Pada penggerombolan data panel multivariat terlebih dahulu menentukan jumlah $\mathrm{k}$ optimum yang akan digunakan. Pada penentuan $\mathrm{k}$ optimum dilakukan dengan nilai Calinski Harabasz yaitu dengan mencoba $\mathrm{k}$-means ketika $\mathrm{k}=2,3,4,5,6$. Penentuan $\mathrm{k}$ optimum Calinski Harabasz dengan membandingkan nilai Calinski Harabasz antar gerombolnya dan memilih nilai terbesar tanpa harus melakukan cut off.

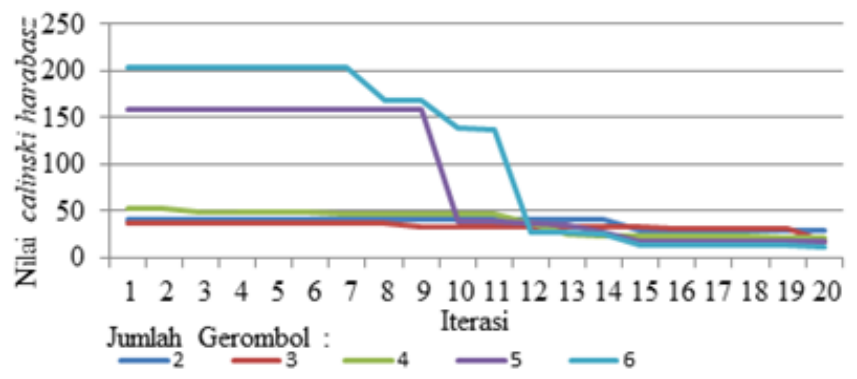

Gambar 5. Grafik nilai calinski harabasz untuk banyak gerombol berbeda pada setiap iterasi

Berdasarkan Gambar 5 terlihat bahwa setiap partisi mewakili jumlah gerombol dan partisi tersebut sudah melewati urutan Calinski Harabasz dari terkecil ke terbesar. Nilai Calinski Harabasz terbesar menghasilkan 6 gerombol dengan nilai terbesar lebih dari 200. Calinski Harabasz dengan $\mathrm{k}=6$ merupakan k optimum yang diperoleh. Nilai k optimum tersebut digunakan untuk analisis k-means longitudinal data dengan package kml3d untuk menentukan objek-objek yang terdapat dalam satu gerombol berdasarkan lintasannya.

Hasil analisis k-means longitudinal data dengan $\mathrm{k}=6$ dapat ditentukan dari iterasi kedelapan dan pertimbangan jumlah objek pada masing-masing gerombolnya. Hasil penggerombolan ini merupakan hasil untuk semua peubah yang digunakan dalam penelitian yaitu biaya produksi, biaya promosi, biaya distribusi, dan nilai penjualan. Pada gerombol 1 terdapat 7 perusahaan, gerombol 2 terdapat 6 perusahaan, gerombol 3 terdapat 4 perusahaan, gerombol 4 terdapat 3 perusahaan, gerombol 2 terdapat 2 perusahaan, dan gerombol 7 terdapat 1 perusahaan.

Tabel X

DAFTAR PERUSAHAAN UNTUK PENGGEROMBOLAN DATA PANEL MULTIVARIAT

\begin{tabular}{ll}
\hline Gerombol & \multicolumn{1}{c}{ Nama perusahaan } \\
\hline 1 & PT Delta Djakarta Tbk, PT Sekar Laut, PT \\
& Akasha Wira International Tbk, PT Pyridam \\
& Farma Tbk, PT Taisho Pharmaceutical Indone- \\
& sia Tbk, PT Langgeng Makmur Industri Tbk, \\
& PT Wismilak Inti Makmur Tbk \\
\hline 2 & PT Indofood CBP Sukses Makmur, PT Mayora \\
& Indah Tbk, PT Unilever Indonesia Tbk, PT \\
& Kalbe Farma Tbk, PT Tempo Scan Pasific Tbk, \\
& PT Bentoel International Investama Tbk \\
\hline 3 & PT Ultra Jaya, PT Multi Bintang Indonesia, PT \\
& Tiga Pilar Sejahtera, PT Kimia Farma Tbk \\
\hline 4 & PT Nippon Indosari Corpindo, PT Siantar Top, \\
& PT Mandom Indonesia Tbk \\
\hline 5 & PT Indofood Sukses Makmur,PT Handjaya \\
& Mandala Sampoerna Tbk \\
\hline 6 & PT Mustika Ratu Tbk \\
\hline
\end{tabular}

Berdasarkan Tabel 10, gerombol 1 terdiri dari dua perusahaan yang berasal dari sektor makanan dan minuman, empat perusahaan kosmetik dan barang keperluan rumah tangga, satu perusahaan peralatan rumah tangga, dan satu perusahaan rokok. Pada gerombol 2 terdiri dari dua perusahaan yang berasal dari sektor makanan dan minuman, tiga perusahaan kosmetik dan barang keperluan rumah tangga, dan satu perusahaan rokok. 
Pada gerombol 3 terdiri dari tiga perusahaan makanan dan minuman dan satu perusahaan kosmetik dan barang keperluan rumah tangga. Gerombol 4 terdiri dari tiga perusahaan kosmetik dan barang keperluan rumah tangga. Pada gerombol 5 terdiri dari satu perusahaan makanan dan minuman, satu perusahaan rokok. Gerombol 6 terdiri dari satu perusahaan kosmetik dan barang keperluan rumah tangga.

Tabel XI

NILAI RATA-RATA SETIAP GEROMBOL TERBENTUK PADA MASING-MASING PEUBAH BERDASARKAN PENGGEROMBOLAN DATA PANEL MULTIVARIAT(TRILIUN RUPIAH)

\begin{tabular}{lrrrr}
\hline Gerombol & Bprod & Bpromo & Bdist & Npenj \\
\hline 1 & 0.3613 & 0.0466 & 0.0201 & 0.8393 \\
2 & 10.9358 & 1.1609 & 0.5633 & 19.2373 \\
3 & 2.3215 & 0.1705 & 0.1131 & 4.0560 \\
4 & 1.3237 & 0.0806 & 0.0753 & 2.0440 \\
5 & 27.3951 & 1.7609 & 1.4609 & 70.9076 \\
6 & 0.1753 & 0.0974 & 0.0085 & 0.4047 \\
\hline
\end{tabular}

Gerombol 5 terdiri dari perusahaan yang secara keseluruhan memiliki rata-rata biaya produksi, ratarata biaya promosi, rata-rata biaya distribusi, dan rata-rata nilai penjualan tertinggi dibadingkan dengan gerombol lainnya. Jika dilihat dari hasil analisis deskriptif, perusahaan gerombol 5 merupakan perusahaan yang tergolong mengeluarkan biaya produksi, biaya promosi, biaya distribusi, dan nilai penjualan yang lebih tinggi dibandingkan perusahaan lain.

Hasil penggerombolan berdasarkan biaya produksi, biaya promosi, biaya distribusi, dan nilai penjualan seperti Tabel 11 dapat dijelaskan oleh grafik perkembangan biaya produksi, biaya promosi, biaya distribusi, dan nilai penjualan masing-masing gerombol dari tahun ke tahun untuk mengetahui karakteristik dari masing-masing gerombol.

Berdasarkan Gambar 6 (a) gerombol 5 berisi perusahaan dengan rata-rata biaya produksi yang mengalami peningkatan dari tahun ke tahun dengan rata-rata biaya produksi lebih dari 20 triliun rupiah dan merupakan gerombol dengan rata-rata biaya

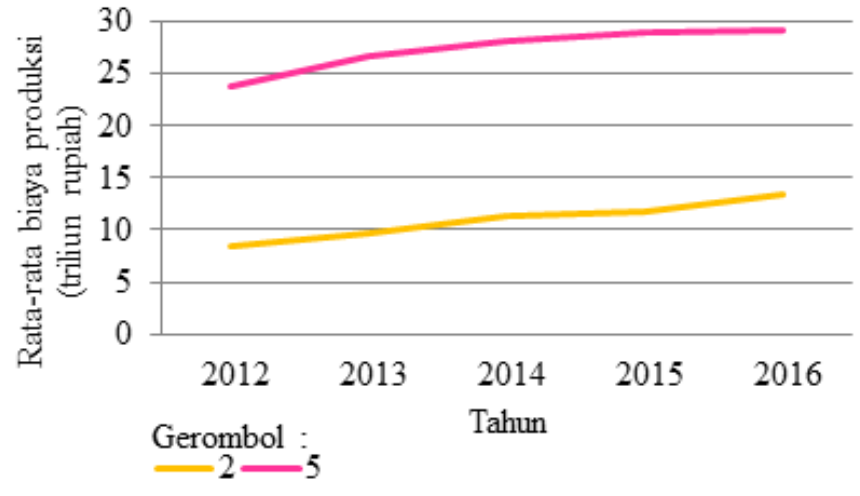

(a)

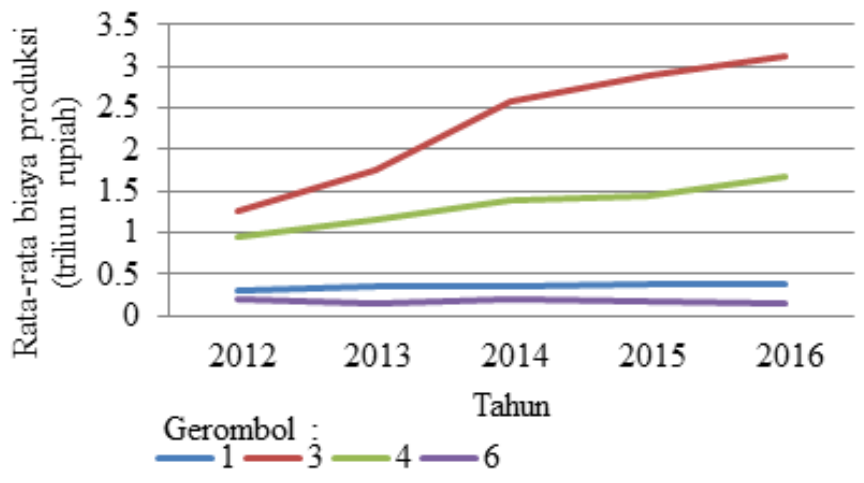

(b)

Gambar 6. Rata-rata biaya produksi (a) Gerombol 2 dan Gerombol 5, (b) Gerombol 1, Gerombol 3, Gerombol 4, dan Gerombol 6

produksi tertinggi. Gerombol 2 berisi perusahaan dengan rata-rata biaya produksi diantara 5 sampai 15 triliun rupiah dan mengalami kenaikan dari tahun ke tahun.

Pada gambar 6 (b) berisi rata-rata biaya produksi gerombol 1,3,4, dan 6. Gerombol 3 berisi perusahaan dengan rata-rata biaya produksi pada tahun 2012 kurang dari 1.5 triliun rupiah dan terus mengalami kenaikan dari tahun ke tahun hingga lebih dari 3 triliun rupiah. Pada gerombol 4 berisi perusahaan dengan rata-rata biaya produksi yang mengalami kenaikan dari tahun ke tahun. Pada tahun 2012, rata-rata biaya produksi gerombol 3 kurang dari 3triliun rupiah dan terus mengalami kenaikan hingga lebih dari 1.5 triliun rupiah.

Gerombol 1 memiliki rata-rata biaya produksi yang terus menerus meningkat dari tahun ke tahun namun kurang dari 0.5 triliun rupiah. Gerombol 
6 memiliki rata-rata biaya produksi dari tahun ke tahun kurang dari 0.5 triliun rupiah dan mengalami penurunan di tahun 2013, 2015, dan 2016. Pemisahaan grafik tersebut disebabkan adanya perbedaan skala yang cukup jauh antar gerombol tersebut.

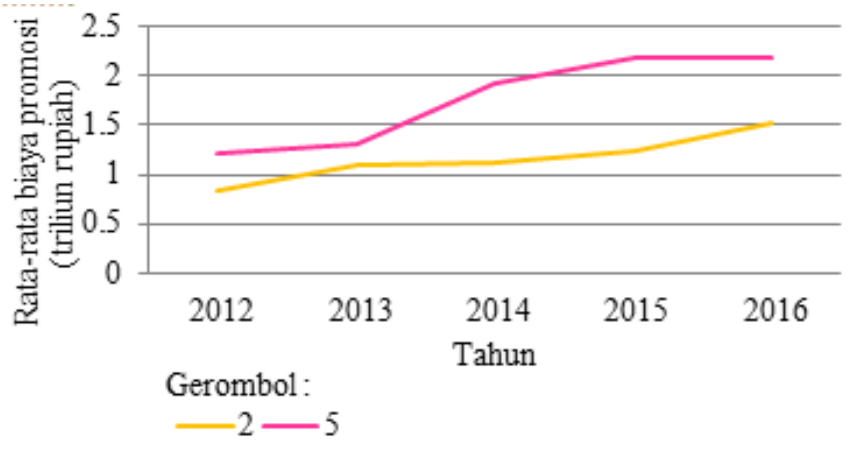

(a)

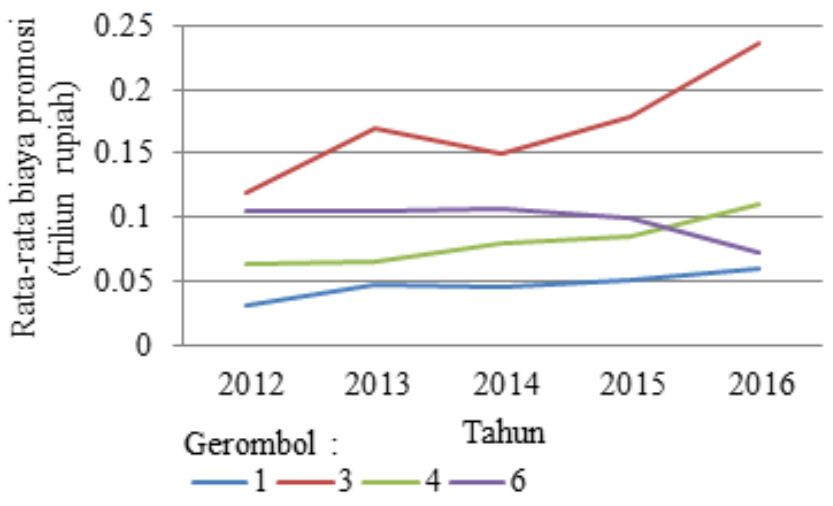

(b)

Gambar 7. Rata-rata biaya promosi (a) Gerombol 2 dan Gerombol 5, (b) Gerombol 1, Gerombol 3, Gerombol 4, dan Gerombol 6

Pada Gambar 7 (a) terlihat gerombol 5 mengalami kenaikan rata-rata biaya promosi dari tahun ke tahun dengan rata-rata biaya produksi lebih tinggi dibandingkan dengan gerombol lain. Pada gerombol 5 ratarata biaya promosi mengalami kenaikan yang cukup signifikan pada tahun 2014 dan terus mengalami kenaikan hingga lebih dari 2 triliun rupiah pada tahun 2015 dan 2016. Gerombol 2 memiliki ratarata biaya promosi tertinggi kedua dengan kenaikan rata-rata biaya promosi yang cukup tinggi pada tahun 2013 dan 2016. Pada tahun 2012 dengan rata-rata biaya promosi kurang dari 1 triliun rupiah dan terus mengalami kenaikan hingga lebih dari 1.5 triliun rupiah pada tahun 2016.
Pada gambar 7 (b) gerombol 3 berisi perusahaan dengan rata-rata biaya promosi yang mengalami penurunan pada tahun 2014 dan terus mengalami kenaikan sampai tahun 2016 dengan rata-rata biaya promosi lebih dari 0.2 triliun rupiah. Gerombol 6 rata-rata biaya promosi cenderung mengalami penurunan pada tahun 2013, 2015, dan 2016. Pada gerombol 4 dan gerombol 1 rata-rata biaya promosi cenderung mengalami kenaikan dari tahun ke tahun namun rata-rata biaya promosi gerombol 1 lebih kecil dibandingkan dengan gerombol 4. Pemisahaan grafik tersebut disebabkan adanya perbedaan skala yang cukup jauh antar gerombol tersebut.

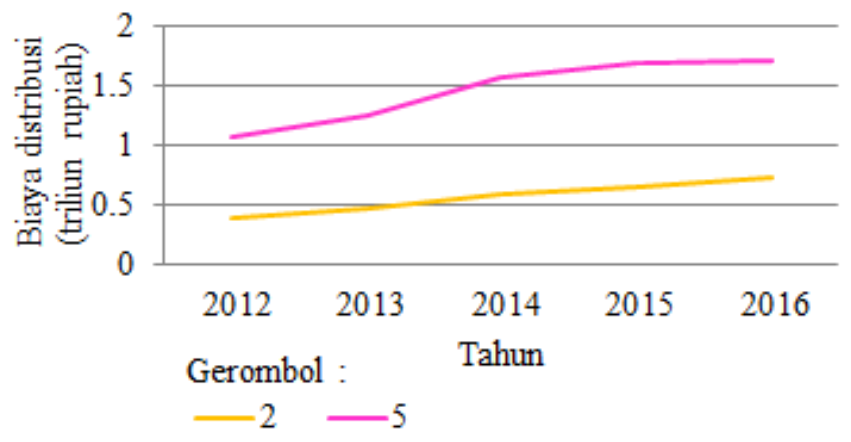

(a)

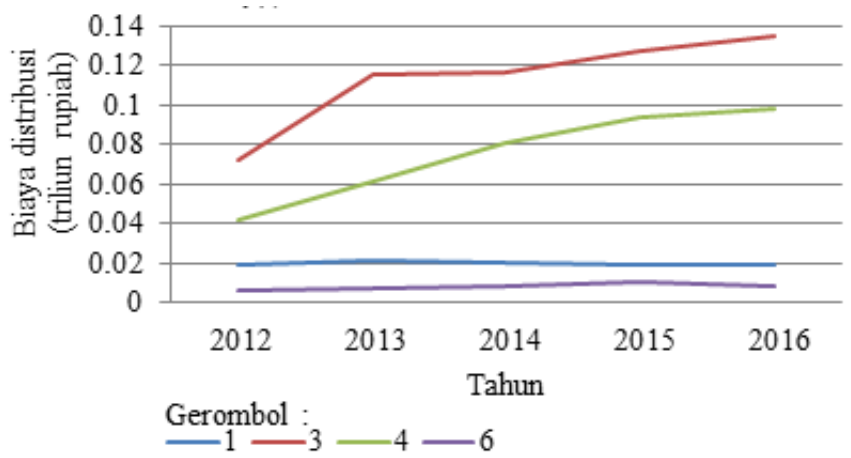

(b)

Gambar 8. Rata-rata biaya promosi (a) Gerombol 2 dan Gerombol 5, (b) Gerombol 1, Gerombol 3, Gerombol 4, dan Gerombol 6

Berdasarkan gambar 8 (a) terlihat gerombol 5 mengalami kenaikan rata-rata biaya distribusi dari tahun ke tahun dengan rata-rata biaya distribusi lebih tinggi dibandingkan dengan gerombol lain. Pada tahun 2012 rata-rata biaya distribusi gerombol 5 lebih dari 1 triliun rupiah dan terus mengalami kenaikan yang cukup tinggi sampai tahun 2015 hingga lebih dari 1.5 triliun rupiah dan sedikit mengalami 
kenaikan pada tahun 2016. Gerombol 2 memiliki rata-rata biaya distribusi tertinggi kedua dan terus mengalami kenaikan rata-rata biaya distribusi dari tahun ke tahun.

Pada gambar 8 (b) rata-rata biaya distribusi gerombol 3 cenderung mengalami sedikit kenaikan dari tahun ke tahun. Pada tahun 2013 mengalami kenaikan rata-rata biaya promosi cukup tinggi dibandingkan tahun sebelumnya dan terus mengalami kenaikan hingga lebih dari 0.12 triliun rupiah. Gerombol 4 memiliki rata-rata biaya distribusi diantara 0.04 hingga 0.1 triliun rupiah.Gerombol 1 memiliki rata-rata biaya distribusi disekitar 0.02 triliun rupiah dan gerombol 6 memiliki rata-rata biaya distribusi yang mengalami penurunan di tahun 2013 dan 2016 dengan rata-rata biaya distribusi kurang dari 0.02 triliun rupiah. Pemisahaan grafik tersebut disebabkan adanya perbedaan skala yang cukup jauh antar gerombol tersebut.

Berdasarkan gambar 9 (a) terlihat gerombol 5 memiliki rata-rata nilai penjualan yang terus meningkat dari tahun ke tahun dan memiliki ratarata nilai penjualan tertinggi dibandingkan gerombol lainnya dengan rata-rata nilai penjualan diantara 50 sampai 90 triliun rupiah. Gerombol 2 memiliki rata-rata nilai penjualan tertinggi kedua dan terus menerus mengalami kenaikan dari tahun ke tahun. Kenaikan terlihat cukup tinggi pada tahun 2012 ke tahun 2014 dan dari tahun 2015 ke tahun 2016. Rata-rata nilai penjualan gerombol 2 berada diantara 10 sampai 30 triliun rupiah.

Pada gambar 9 (b) gerombol 3 terlihat mengalami kenaikan rata-rata penjualan yang cukup tinggi setelah tahun 2013 dengan rata-rata nilai penjualan diantara 2.5 sampai 5.5 triliun rupiah. Pada gerombol 4 terlihat rata-rata nilai penjualan mengalami kenaikan dari tahun ke tahun namun pada tahun 2013 hanya mengalami sedikiti kenaikan. Gerombol 1 memiliki rata-rata nilai penjualan yang terus meningkat dari tahun ke tahun dengan rata-rata nilai penjualan diantara 0.5 sampai 1 triliun rupiah. Gerombol 6 memiliki rata-rata nilai penjualan yang tidak stabil dari tahun ke tahun yang mengalami penurun pada tahun 2013 dan tahun 2016 dengan rata-rata nilai penjualan kurang dari 0.5 triliun rupiah. Pemisahaan grafik tersebut disebabkan adanya perbedaan skala yang cukup jauh antar gerombol tersebut.

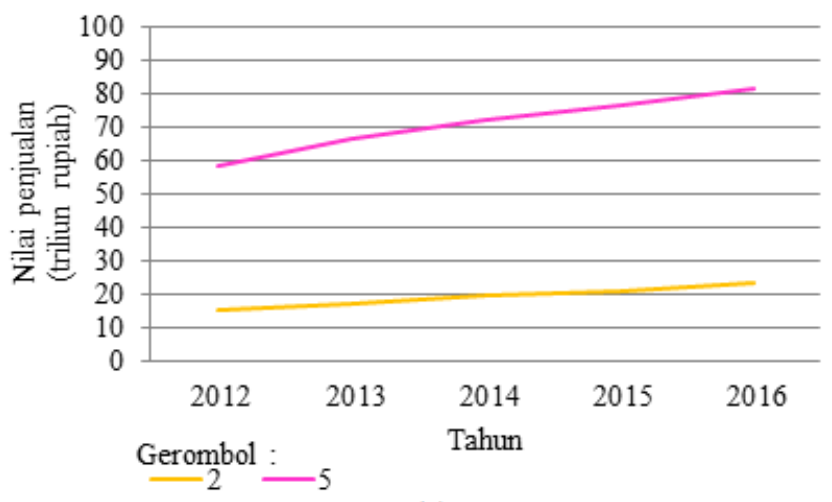

(a)

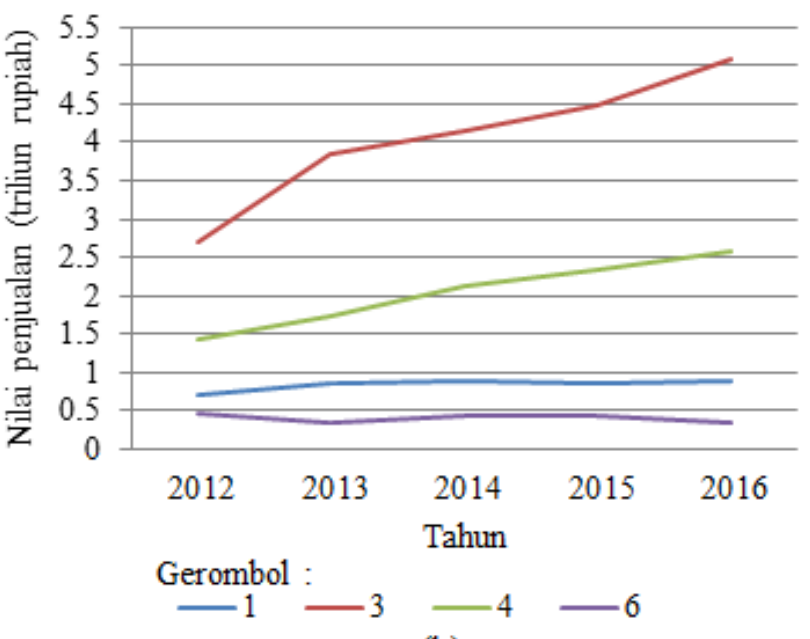

(b)

Gambar 9. Rata-rata nilai penjualan (a) Gerombol 2 dan Gerombol 5, (b) Gerombol 1, Gerombol 3, Gerombol 4, dan Gerombol 6

\section{SIMPULAN}

\section{A. Simpulan}

Hasil penelitian penggerombolan data panel terhadap perusahaan sektor barang konsumsi dengan penggerombolan metode ward menghasilkan 2 gerombol berdasarkan masing-masing peubah yang digunakan yaitu biaya produksi, biaya promosi, biaya distribusi, dan nilai penjualan. Gerombol 2 pada masing-masing peubah menunjukkan perusahaan dengan pola rata-rata biaya produksi, rata-rata biaya promosi, rata-rata biaya distribusi, dan ratarata nilai penjualan tertinggi dibandingkan gerombol 1. Secara keseluruhan, perusahaan yang tergolong dalam nilai 4 peubah faktor manajemen pemasaran tertinggi terdapat pada gerombol 2 yaitu PT Indofood CBP Sukses Makmur, PT Indofood 
Sukses Makmur, PT Mayora Indah, PT Unilever Indonesia Tbk, PT Handjaya Mandala Sampoerna Tbk, International Investama Tbk, PT Kalbe Farma Tbk, dan PT Tempo Scan Pasific Tbk. Penggerombolan secara data panel multivariat dengan metode k-means menghasilkan 6 gerombol. Gerombol 5 merupakan gerombol dengan rata-rata nilai tertinggi secara keseluruhan peubah faktor manajemen pemasaran dibandingkan gerombol lain. Perusahaan pada gerombol 5 yaitu PT Indofood Sukses Makmur dan PT Handjaya Mandala Sampoerna Tbk. Hal ini juga sesuai dengan hasil penggerombolan berdasarkan setiap peubah faktor manajemen pemasaran.

\section{DAFTAR PUSTAKa}

Ardiyoso (2007). Kamus standar akuntansi. Jakarta (ID): Penerbit Citra Harta Prima.

Calinski, T. and J. Harazbasz (1974). A dendrit method for cluster analysis. Communication in statistic 3(1), 1-27.

Genolini, C., A. Xavier, S. Mariane, and A. Catherine (2015). $\mathrm{Kml}$ and $\mathrm{kml3d}: \mathrm{R}$ packages to cluster longitudinal data. Jurnal of Statistical Software 65.

Ilmarinen, P., E. Leena, N. Onni, T. Minna, H. Jussi, and K. Hannu (2007). Cluster Analysis on Longitudinal Data of Patients with Adult-Onset Asthma. Amerika (US): Elsevier Inc.

Johnson, R. and D. Wichern (2007). Apllied Multivariate Statistical Analysis Edisi ke-9. New jersey (US): Pearson Prentice Hall.

Prasetyo, E. (2012). Data Mining : Konsep dan Aplikasi menggunakan MATLAB. Yogyakarta (ID): CV Andi Offset.

Riwayadi (2006). Akuntansi Biaya. Padang (ID): Andalas University Press.

William, K., Carter, and M. Usry (2004). Akuntansi Biaya Edisi ke-8 Jilid 2. Jakarta (ID): Salemba Empat.

Winarno, W. (2007). Analisis Ekonometrika dan Statistika dengan Eviews Edisi ke-1. Yogyakarta (ID): UPP STIM YKPN. 